\title{
113
}

\section{GENOTIPI E VIREMIA HCV ED HBV IN PAZIENTI CON EPATITE CRONICA B ASSOCIATA AD INFEZIONE DA HCV}

Minchella P., Leone R.A., Nisticò S., Potente G.I., Caruso D., Camerino M., Gagliardi B., Nicolazzo A., Luciano A.

\section{U.O. Microbiologia e Virologia, Azienda Sanitaria N. 6,} Via Perugini I, 88046 Lamezia Terme (CZ)

Introduzione. La duplice infezione $\mathrm{HBV}$ ed $\mathrm{HCV}$, che si riscontra più frequentemente in gruppi a rischio come i tossicodipendenti, è clinicamente molto rilevante, soprattutto per l'aumentato rischio di evoluzione in cirrosi ed epatocarcinoma. L'interazione tra $\mathrm{i}$ due virus in termini di attività replicativa ed effetto citopatico sulle cellule epatiche è ancora poco conosciuto.

Scopo di questo lavoro è valutare il profilo virologico, in particolare viremia e genotipi di HCV e di HBV in un gruppo di 13 pazienti con epatite cronica B associata ad infezione da HCV.

Metodi. A) markers sierologici: Meia (Axsym, Abbott); B) HBV-DNA: PCR quantitativa (Cobas Amplicor HBV Monitor, Roche Diagnostics); C) HCV-RNA: PCR qualitativa e quantitativa (Cobas Amplicor HCV e Cobas Amplicor HCV Monitor, Roche Diagnostics); D) Genotipo HCV: ibridazione inversa su strips (HCV Genotype Assay LiPA, Bayer); E) Genotipo HBV: ibridazione inversa su strips (INNO-LiPA HBV Genotyping, Innogenetics).

Risultati. Nei 13 pazienti $\mathrm{HBsAg} /$ anti-HCV positivi (9 maschi e 4 femmine, con età media di circa 44 anni) la viremia HBV ed HCV presentava il seguente quadro.

\begin{tabular}{cc}
\hline Viremia HCV ed HBV & Casi \\
\hline HCV-RNA + / HBV-DNA + & 4 \\
\hline HCV-RNA + / HBV-DNA - & 3 \\
\hline HCV-RNA - / HBV-DNA + & 3 \\
\hline HCV-RNA - / HBV-DNA - & 3 \\
\hline
\end{tabular}

Nei 7 soggetti HCV-RNA positivi la viremia era in 6 superiore a $400.000 \mathrm{UI} / \mathrm{ml}$, mentre solo in uno era bassa, circa $2.000 \mathrm{UI} / \mathrm{ml}$; per quanto riguarda il genotipo $\mathrm{HCV} \mathrm{n.} 4$

pazienti erano genotipo 3a, n. 1 2a/2c, n. 1 4c/4d, n. 1 genotipo 1.

Negli stessi 13 pazienti considerati, l'HBV-DNA è risultato positivo in 7 casi, con viremia molto elevata (mediamente alcuni milioni di copie/ml) in 4 pazienti e relativamente bassa (circa 20.000 copie/ml) negli altri 3; in 6 soggetti è stato riscontrato il genotipo $\mathrm{D}$, il più frequente nell'area mediterranea, mentre in uno solo è il genotipo A. Da una indagine anamnestica sui 13 pazienti HBsAg/anti-HCV positivi abbiamo riscontrato che tra i soggetti con età inferiore ai 40 anni era diffuso l'uso di sostanze per via endovenosa. Conclusioni. Numerose osservazioni cliniche hanno rilevato che molti soggetti HBsAg/anti-HCV positivi presentano bassi livelli di viremia $\mathrm{HBV}$ ed elevata carica virale $\mathrm{HCV}$, ma nei nostri pazienti non è stata trovata evidenza di soppressione della replicazione di $\mathrm{HBV}$ da parte di $\mathrm{HCV}$. 